\title{
Özofajektomi Sonrası Pulmoner Komplikasyon Gelişen Olgular ve Tedavi Yaklaşımları
}

\author{
Mehmet Erdem Çakmak ${ }^{1} \oplus$, Hayriye Cankar Dal'®, Derya Ademoğlu' ${ }^{1} \oplus$, \\ Serdar Yamanyar' ${ }^{1} \odot$, Büşra Tezcan ${ }^{1} \odot$, Dilek Kazancı ${ }^{1} \odot$, Ayşegül Özgö $k^{2} \oplus$, Sema Turan ${ }^{1} \oplus$
}

'Türkiye Yüksek Intisas Hastanesi, Yoğun Bakım Anabilim Dalı, Ankara, Türkiye

${ }^{2}$ Türkiye Yüksek Ihtisas Hastanesi, Anestezi ve Reanimasyon Anabilim Dalı, Ankara, Türkiye

Mehmet Erdem Çakmak, Uzm. Dr. Hayriye Cankar Dal, Uzm. Dr. Derya Ademoğlu, Uzm. Dr. Serdar Yamanyar, Uzm. Dr. Büşra Tezcan, Uzm. Dr. Dilek Kazancı, Doç. Dr. Ayşegül Özgök, Prof. Dr. Sema Turan, Doç. Dr.

\section{İletişim:}

Uzm. Dr. Mehmet Erdem Çakmak Türkiye Yüksek Ihtisas Hastanesi, Yoğun Bakım Anabilim Dalı, Ankara, Türkiye Tel: +90505 4869750

E-Posta: erdem.cakmak@deu.edu.tr

Gönderilme Tarihi : 10 Haziran 2017 Revizyon Tarihi : 29 Ekim 2017 Kabul Tarihi : : 02 Kasım 2017
ÖZET

Subtotal özofajektomi mide serbestleştirilmesi sonrası torakotomi ile özofajektomi ve özofagogastrik anastomozu içerir. Özofagus karsinomunda, yüksek dereceli displazide, kostik özofageal yaralanmalarda uygulanabilir. Bu operasyon sonrası atelektazi, pnömoni, aspirasyon ve uzamış entübasyon gerektiren solunum yetmezliği pulmoner komplikasyon olarak görülebilir. Pulmoner komplikasyonların oranı $\% 20$ ile $\% 50$ arasında değişmektedir. Pulmoner komplikasyon gelişimi hastanede kalıs süresini uzatmanın yanı sıra mortalite ve morbiditeyi anlamlı oranda arttırmaktadır. Bu çalışmada postoperatif pulmoner komplikasyon gelişen 5 olguyu retrospektif olarak değerlendirdik. Olguların postoperatif dönemde 4 tanesinde pnömoni, 1'inde atelektazi, 1'inde pnömotoraks ve cilt altı amfizem geliştiği saptandı. Bir hasta postoperatif dönemde anastomoz kaçağına bağlı exitus oldu. Dikkatli bir preoperatif değerlendirme ve uygun postoperatif önlemler ile pulmoner komplikasyon oranları azaltılabilir. Bu çalışmada özofagus cerrahisi sonrası postoperatif pulmoner komplikasyon gelişen olguları değerlendirmeyi amaçladık.

Anahtar sözcükler: Özofajektomi, akciğer, komplikasyonlar

\section{PATIENTS WITH PULMONARY COMPLICATIONS AFTER ESOPHAGECTOMY AND TREATMENT APPROACHES}

\section{ABSTRACT}

Subtotal esophagectomy involves esophagectomy and esophagogastric anastomosis with thoracotomy after gastric release(emptying). It can be performed to remove esophageal carcinomas, high - grade dysplasia, and caustic esophageal injuries. Atelectasis, pneumonia, aspiration and prolonged respiratory failure may occur as pulmonary complications in the postoperative period. The rate of pulmonary complications ranges from $20 \%$ to $50 \%$. The development of pulmonary complications not only prolongs the hospital stay but it also increases the mortality and morbidity significantly. In this study, we retrospectively evaluated 5 cases with postoperative pulmonary complications. Postoperatively, 4 cases had pneumonia, 1 had atelectasis, 1 had a pneumothorax and subcutaneous emphysema. One patient died in the postoperative period due to anastomotic leakage. Pulmonary complication rates can be reduced with careful preoperative evaluation and appropriate postoperative measures. In this study, we aimed to evaluate the postoperative pulmonary complications after esophageal surgery.

Keywords: Esophagectomy, lung, complications

zofajektomi, özellikle rezeksiyonu mümkün olan özofagus kanserlerinde standart tedavi yöntemidir. 1946'da Lewis laparatomi ve sağ torakotomi ile gerçekleştirilen subtotal özofajektomiyi tanımladı (1). Subtotal özofajektomi 2 basamaklı bir cerrahi işlem olup laparatomi ile mide serbestleştirilmesi sonrası torakotomi ile yapılan özofajektomi ve özofagogastrik anastomozu içerir. Özofagus karsinomunda, yüksek dereceli displazide, kostik özofageal yaralanmalarda kullanılabilir 
(2). Üst 1/3 özofagusu içeren karsinomlarda yeterli cerrahi sınır elde edilemeyeceği için tercih edilmez. Servikal lenf nodu diseksiyonu yapılamaması, intratorasik anastomozda kaçak meydana gelmesi durumunda sepsis riskinin yüksek olması operasyonun dezavantajlarıdır (3). Atelektazi, pnömoni, aspirasyon ve uzamış entübasyon gerektiren solunum yetmezliği postoperatif dönemde pulmoner komplikasyon olarak görülebilir. Bu olgu sunumunda, özofagus kanserli beş olguda uygulanan subtotal özofajektomi sonrası oluşan postoperatif pulmoner komplikasyonları değerlendirmeyi amaçladık.

\section{Olgu sunumu}

Preoperatif pulmoner değerlendirmesinde herhangi bir akciğer hastalığı olmayan özofagus kanseri tanısı almış beş hastaya subtotal özofajektomi uygulandı. Yazılı hasta onamı hastaların ailelerinden alındı. Hastalara ait bilgiler Tablo 1 de özetlenmiştir.

\section{Olgu 1}

45 yaşında erkek hasta, özofagus ca tanısı aldıktan sonra hastaya laparatomi ile mide serbestleştirilmesini takiben sağ torakotomi ile subtotal özofajektomi ve özofagogastrik anastomoz cerrahisi uygulandı. Preoperatif değerlendirmesinde hastanın hipertansiyon dışında ek hastalığı yoktu. Postoperatif 3. günde hastada gelişen solunum sıkıntısı nedeniyle yoğun bakımda izleme alındı. Yoğun bakım yatışında kalp atım hızı 100/dk, kan basıncı 145/85 $\mathrm{mmHg}$, solunum sayısı $32 / \mathrm{dk}$, ateşi $38^{\circ} \mathrm{C}$, solunum sistemi fizik muayenesinde hastanın her iki akciğerinde ralleri vardı. Tam kan sayımında beyaz küre: 13.800, CRP düzeyi
$45 \mathrm{mg} / \mathrm{L}$ saptand, koagülasyon parametreleri, renal ve hepatik fonksiyon testleri normaldi. Hasta elektif entübe edilerek mekanik ventilatör desteğinde izleme alındı. Plato basıncı $<30 \mathrm{~cm} \mathrm{H2O}$ olacak şekilde basınç kontrollü mekanik ventilasyon uygulandı. Postoperatif dönemde ağrı kontrolü amaçlı torakal epidural kateter ile bupivakain + fentanil hastaya uygulandı. Ortalama arter basıncı 65 $\mathrm{mmHg}$ ve üzerinde olacak şekilde ve santral venöz basınç takibi yapılarak intravenöz kristaloid sıvı replasmanı yapıldı. Hastanın çekilen toraks bilgisayarlı tomografisinde sağ ve sol akciğer alt lobda pnömonik konsolidasyonla uyumlu görünüm saptandı (Şekil 1). Endotrakeal aspirat kültüründe klebsiella pneumoniae üreyen hastaya piperasilin tazobaktam başlandı. İzlemde pnömonisi gerileyen hasta mekanik ventilatör desteğinin 10. gününde extübe edildi. Mekanik ventilatörden ayrıldıktan sonra hastaya solunum fizyoterapisi ve öksürme egzersizleri uygulandı. Hasta şifa ile taburcu edildi.

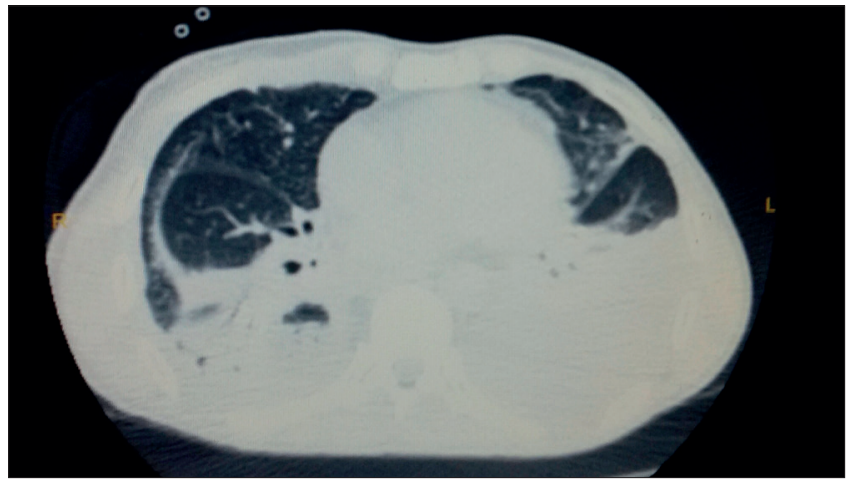

Şekil 1. Sağ ve sol akciğer alt lobda pnömonik konsolidasyonla uyumlu görünüm

Tablo 1. Olgulara ait genel özellikler

\begin{tabular}{|c|c|c|c|c|c|}
\hline & Olgu 1 & Olgu 2 & Olgu 3 & Olgu 4 & Olgu 5 \\
\hline Yaş & 45 & 65 & 75 & 55 & 55 \\
\hline Cinsiyet & Erkek & Kadın & Erkek & Kadın & Erkek \\
\hline Tanı & Özofagus ca & Özofagus ca & Özofagus ca & Özofagus ca & Özofagus ca \\
\hline Cerrahi & $\begin{array}{c}\text { Subtotal } \\
\text { özofajektomi }\end{array}$ & $\begin{array}{c}\text { Subtotal } \\
\text { özofajektomi }\end{array}$ & $\begin{array}{c}\text { Subtotal } \\
\text { özofajektomi }\end{array}$ & $\begin{array}{c}\text { Subtotal } \\
\text { özofajektomi }\end{array}$ & $\begin{array}{c}\text { Subtotal } \\
\text { özofajektomi }\end{array}$ \\
\hline Komplikasyon & Pnömoni & $\begin{array}{l}\text { Pnömoni } \\
\text { Atelektazi }\end{array}$ & $\begin{array}{l}\text { Pnömoni } \\
\text { Sepsis }\end{array}$ & $\begin{array}{l}\text { Pnömotoraks } \\
\text { Cilt altı amfizem }\end{array}$ & Pnömoni \\
\hline Apache II & 6 & 7 & 23 & 7 & 10 \\
\hline ASA & 2 & 2 & 3 & 2 & 2 \\
\hline Mekanik ventilasyon(gün) & 10 gün & 8 gün & 30 gün & 7 gün & 30 gün \\
\hline Trakeostomi & Açılmadı & Açılmadı & Açıldı & Açılmadı & Açıldı \\
\hline Kültür (ETA) & $\begin{array}{c}\text { Klebsiella } \\
\text { Pneumoniae }\end{array}$ & $\begin{array}{l}\text { Acinetobacter } \\
\text { baumannii }\end{array}$ & $\begin{array}{l}\text { Klebsiella } \\
\text { Pneumoniae }\end{array}$ & Üreme yok & $\begin{array}{l}\text { Acinetobacter } \\
\text { baumannii }\end{array}$ \\
\hline Antibiyogram & $\begin{array}{l}\text { Piperasilin } \\
\text { tazobaktam }\end{array}$ & $\begin{array}{l}\text { Meropenem } \\
\text { B- laktam }\end{array}$ & Meropenem & Yok & $\begin{array}{l}\text { Meropenem } \\
\text { B-laktam }\end{array}$ \\
\hline Hastanede kalış (gün) & 35 gün & 24 gün & 45 gün & 26 gün & 40 gün \\
\hline Mortalite & Şifa & Şifa & Exitus & Şifa & Şifa \\
\hline
\end{tabular}




\section{Olgu 2}

65 yaşında bayan hasta, özofagus ca tanısı aldıktan sonra hastaya laparatomi ile mide serbestleştirilmesini takiben sağ torakotomi ile subtotal özofajektomi ve özofagogastrik anastomoz cerrahisi uygulandı. Preoperatif değerlendirmesinde hastanın diabetes mellitus dışında ek hastalığı yoktu. Postoperatif 4. günde hastada gelişen solunum sıkıntısı nedeniyle yoğun bakımda izleme alındı. Yoğun bakım yatışında kalp atım hızı 96/dk, kan basıncı 135/70 $\mathrm{mmHg}$, solunum sayısı $34 / \mathrm{dk}$, ateşi $37,8^{\circ} \mathrm{C}$, solunum sistemi fizik muayenesinde hastanın sağ akciğerinde ralleri vardı ve sol akciğerinde solunum sesleri azalmıştı. Tam kan sayımında beyaz küre: 15.200, CRP düzeyi 74 mg/L saptandı, koagülasyon parametreleri, renal ve hepatik fonksiyon testleri normaldi. Hasta elektif entübe edilerek mekanik ventilatör desteğinde izleme alındı. Plato basın$\mathrm{Cl}<30 \mathrm{~cm} \mathrm{H} 2 \mathrm{O}$ olacak şekilde basınç kontrollü mekanik ventilasyon uygulandı. Postoperatif dönemde ağrı kontrolü amaçlı torakal epidural kateter ile bupivakain + fentanil hastaya uygulandı. Ortalama arter basıncı $65 \mathrm{mmHg}$ ve üzerinde olacak şekilde ve santral venöz basınç takibi yapılarak intravenöz kristaloid SIVı replasmanı yapıldı. Hastanın çekilen akciğer grafisi ve toraks bilgisayarlı tomografisinde sol akciğer alt lobda atelektazi (Şekil 2) ve sağ akciğer alt zonda pnömonik konsolidasyonla uyumlu görünüm (Şekil 3) saptandı. Endotrakeal aspirat kültüründe acinetobacter baumannii üreyen hastaya meropenem ve b-laktam antibiyoterapisi başlandı. İzlemde pnömonisi ve atelektazisi gerileyen hasta mekanik ventilatör desteğinin 8. gününde extübe edildi. Mekanik ventilatörden ayrıldıktan sonra hastaya solunum fizyoterapisi ve öksürme egzersizleri uygulandı. Hasta şifa ile taburcu edildi.

\section{Olgu 3}

75 yaşında erkek hasta, özofagus ca tanısı aldıktan sonra hastaya laparatomi ile mide serbestleştirilmesini takiben sağ torakotomi ile subtotal özofajektomi ve özofagogastrik anastomoz cerrahisi uygulandı. Preoperatif değerlendirmesinde hastanın hipertansiyon, diabetes mellitus ve kronik böbrek yetmezliği dışında ek hastalığı yoktu. Postoperatif 2. günde hastada gelişen solunum sıkıntısı nedeniyle yoğun bakımda izleme alındı. Yoğun bakım yatışında kalp atım hızı 110/dk, kan basıncı 95/62 mmHg, solunum sayısı $38 / \mathrm{dk}$, ateşi $38^{\circ} \mathrm{C}$, solunum sistemi fizik muayenesinde hastanın her iki akciğerinde ralleri vardı. Tam kan sayımında beyaz küre: 17.400, CRP düzeyi 95 mg/L, BUN 75 mg/dl kreatinin 3.3 mg/dl saptandı, koagülasyon parametreleri ve hepatik fonksiyon testleri normaldi. Hasta elektif entübe edilerek mekanik ventilatör desteğinde izleme alındı. Plato basıncı $<30 \mathrm{~cm} \mathrm{H2O} \mathrm{olacak}$ şekilde basınç kontrollü mekanik ventilasyon uygulandı.
Postoperatif dönemde ağrı kontrolü amaçlı torakal epidural kateter ile bupivakain + fentanil hastaya uygulandı. Ortalama arter basıncı $65 \mathrm{mmHg}$ ve üzerinde olacak şekilde ve santral venöz basınç takibi yapılarak intravenöz kristaloid sıvı replasmanı yapıldı. Hastanın çekilen toraks bilgisayarlı tomografisinde sağ ve sol akciğer alt lobda pnömonik konsolidasyonla uyumlu görünüm saptandı (Şekil 4). Endotrakeal aspirat kültüründe klebsiella pneumoniae

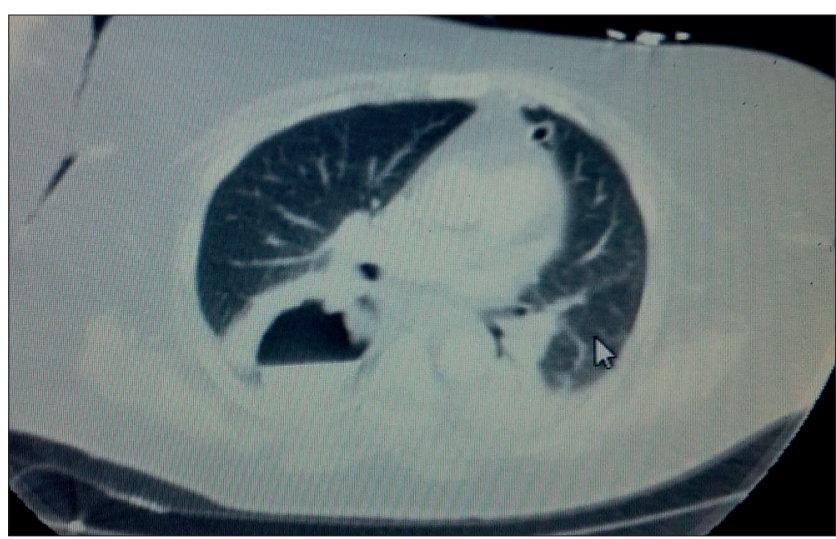

Şekil 2. Sol akciğer alt lobda atelektaziyle uyumlu görünüm

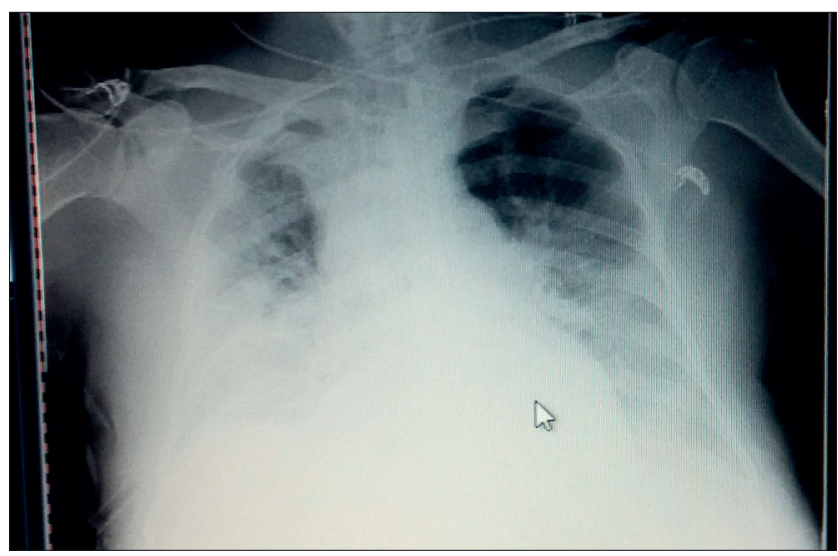

Şekil 3. Sağ akciğer alt zonda pnömonik konsolidasyonla uyumlu görünüm

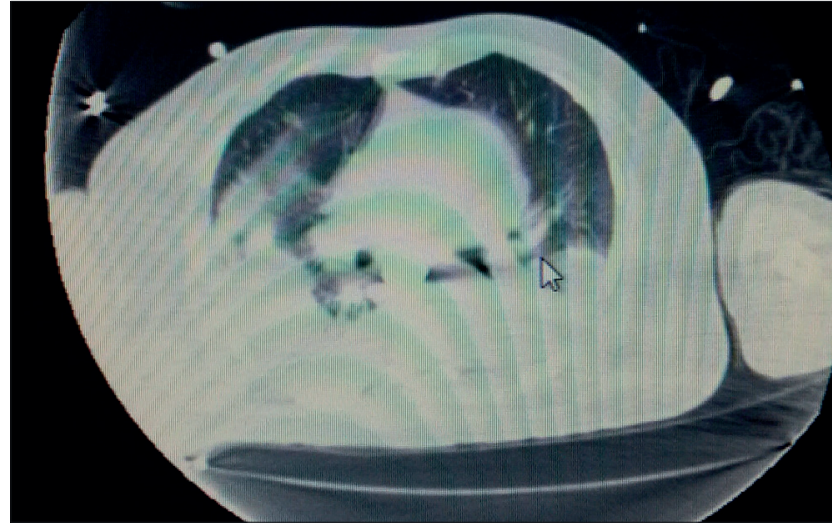

Şekil 4. Sağ ve sol akciğer alt lobda pnömonik konsolidasyonla uyumlu görünüm 
üreyen hastaya meropenem antibiyoterapisi başlandı. Uzamış entübasyona sekonder hastaya perkütan trakeostomi açıldı. Takiplerinde hastada anastomoz kaçağı düşünülerek operasyon lojuna stent uygulandı. İzlemde septik şok gelişen hasta hastanede yatışının 45 . gününde exitus oldu.

\section{Olgu 4}

55 yaşında bayan hasta, özofagus ca tanısı aldıktan sonra hastaya laparatomi ile mide serbestleştirilmesini takiben sağ torakotomi ile subtotal özofajektomi ve özofagogastrik anastomoz cerrahisi uygulandı. Preoperatif değerlendirmesinde hastanın hipertansiyon dışında ek hastalığı yoktu. Postoperatif 3. günde hastada gelişen solunum sıkıntısı nedeniyle yoğun bakımda izleme alındı. Yoğun bakım yatışında kalp atım hızı 90/dk, kan basıncı $130 / 75 \mathrm{mmHg}$, solunum sayısı $40 / \mathrm{dk}$, ateşi $37,2^{\circ} \mathrm{C}$, solunum sistemi fizik muayenesinde hastanın her iki akciğerinde solunum sesleri azalmıştı. Tam kan sayımında beyaz küre: 11.100, CRP düzeyi 14 mg/L saptandı, koagülasyon parametreleri, renal ve hepatik fonksiyon testleri normaldi. Hasta elektif entübe edilerek mekanik ventilatör desteğinde izleme alındı. Plato basıncı $<30$ cm H2O olacak şekilde basınç kontrollü mekanik ventilasyon uygulandı. Postoperatif dönemde ağrı kontrolü amaçlı torakal epidural kateter ile bupivakain + fentanil hastaya uygulandı. Ortalama arter basıncı $65 \mathrm{mmHg}$ ve üzerinde olacak şekilde ve santral venöz basınç takibi yapılarak intravenöz kristaloid sıvı replasmanı yapıldı. Çekilen toraks bilgisayarlı tomografisinde pnömotoraks ve cilt altı amfizemle uyumlu görünüm saptandı (Şekil 5). Hastaya tüp torakostomi uygulandı. İzlemde pnömotoraksı gerileyen hastanın göğüs tüpü çekilerek mekanik ventilasyon desteğinin 7. gününde extübe edildi. Mekanik ventilatörden ayrıldıktan sonra hastaya solunum fizyoterapisi ve öksürme egzersizleri uygulandı. Hasta şifa ile taburcu edildi.

\section{Olgu 5}

55 yaşında erkek hasta, özofagus ca tanısı aldıktan sonra hastaya laparatomi ile mide serbestleştirilmesini takiben sağ torakotomi ile subtotal özofajektomi ve özofagogastrik anastomoz cerrahisi uygulandı. Preoperatif değerlendirmesinde hastanın diabetes mellitus dışında ek hastalığı yoktu. Postoperatif 3. günde hastada gelişen solunum sıkıntısı nedeniyle yoğun bakımda izleme alındı. Yoğun bakım yatışında kalp atım hızı 102/dk, kan basıncı 120/60 mmHg, solunum sayısı $38 / \mathrm{dk}$, ateşi $38,8^{\circ} \mathrm{C}$, solunum sistemi fizik muayenesinde hastanın her iki akciğerinde ralleri vardı. Tam kan sayımında beyaz küre: 14.400, CRP düzeyi 118 mg/L saptandı, koagülasyon parametreleri, renal ve hepatik fonksiyon testleri normaldi. Hasta elektif entübe edilerek mekanik ventilatör desteğinde izleme alındı. Plato basıncı < $30 \mathrm{~cm}$ H2O olacak şekilde basınç kontrollü mekanik ventilasyon uygulandı. Postoperatif dönemde ağrı kontrolü amaçlı torakal epidural kateter ile bupivakain + fentanil hastaya uygulandı. Ortalama arter basıncı 65 $\mathrm{mmHg}$ ve üzerinde olacak şekilde ve santral venöz basınç takibi yapılarak intravenöz kristaloid sıvı replasmanı yapıldı. Hastanın çekilen toraks bilgisayarlı tomografisinde sağ ve sol akciğerde pnömonik konsolidasyonla uyumlu görünüm saptandı (Şekil 6). Endotrakeal aspirat kültüründe acinetobacter baumannii üreyen hastaya meropenem ve b-laktam antibiyoterapisi başlandı. Hasta uzamış entübasyon nedeniyle mekanik ventilatörden ayrılamadı ve trakeostomi açıldı. Hastaya solunum fizyoterapisi ve öksürme egzersizleri uygulandı. İzlemde pnömonisi ve solunum sıkıntısı gerileyen hastanın trakeostomisi kapatılarak şifa ile taburcu edildi.

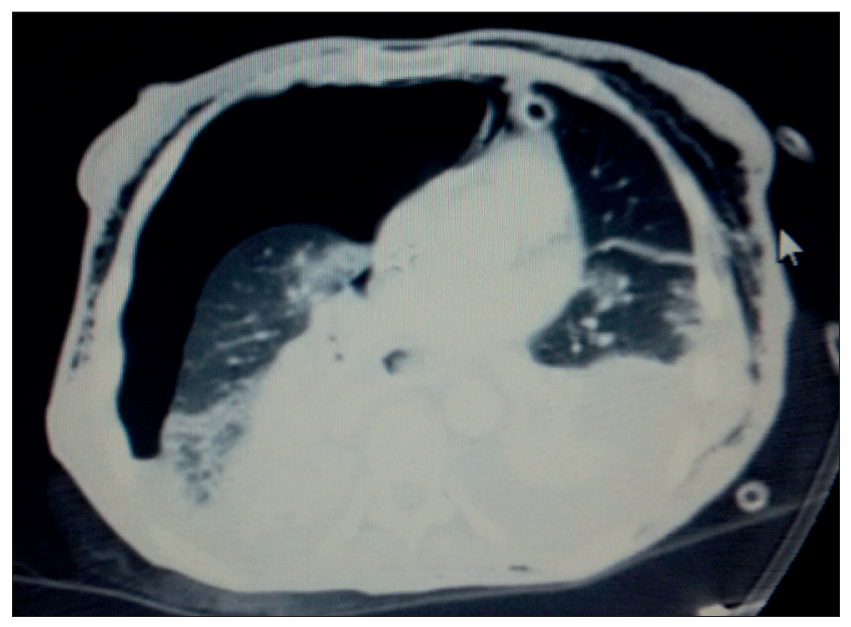

Şekil 5. Pnömotoraks ve cilt altı amfizemle uyumlu görünüm

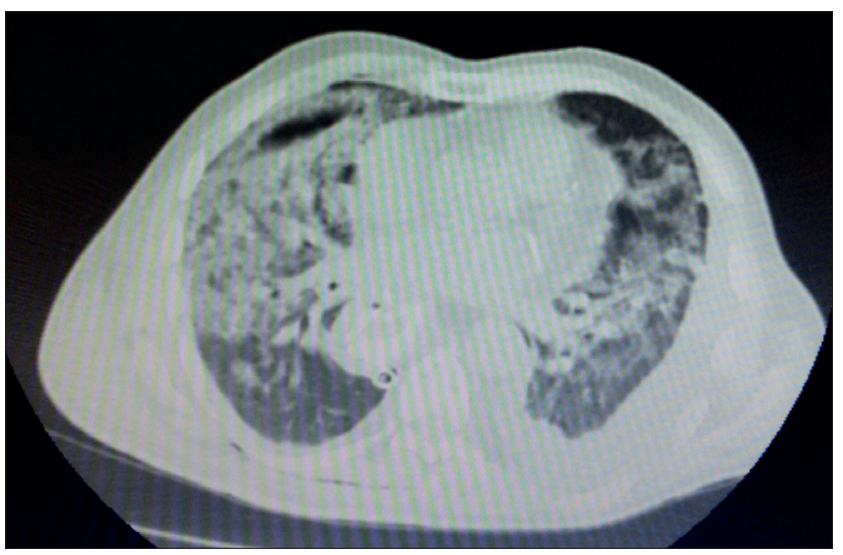

Şekil 6. Her iki akciğerde pnömoni ile uyumlu görünüm 


\section{Tartışma}

Özofajektomi operasyonlarını takiben oluşan komplikasyonlar postoperatif dönemde mortaliteyi önemli ölçüde etkiler. Pulmoner komplikasyonlar ve anastomoz kaçakları hala en ciddi komplikasyonlar olup erken tanı ve uygun tedavi gereklidir. Postoperatif dönemde pnömoni, atelektazi, aspirasyon ve uzamış entübasyon gerektiren solunum yetmezliği görülebilir. Pulmoner komplikasyonların oranı \%20 ile \%50 arasında değişmektedir. Beslenme yetersizliği ve aşırı sigara içme öyküsü olan özofagus kanserli hastalarda pulmoner komplikasyon riski artmaktadır.

Özellikle toraks ve üst abdominal cerrahilerde fonksiyonel rezüdüel kapasite azalması ve bununla ilişkili postoperatif komplikasyon riski diğer bölgelere göre daha yüksektir. Operasyon süresinin uzaması da komplikasyon riskini oldukça artırır. Diyafram disfonksiyonu nedeniyle yukarı doğru yer değiştirmeside akciğer dokusunun kompresyonu ve sürfaktan kaybı atelektazi oluşumuna katkıda bulunur (4). Biz de postoperatif dönemde mekanik ventilasyon desteğindeki hastalarımıza atelektazileri önelemek ve barotravmadan kaçınmak amaçlı plato basıncı $<30 \mathrm{~cm} \mathrm{H} 2 \mathrm{O}$ olacak şekilde uygun peep desteğinde basınç kontrollü mekanik ventilasyon uyguladık.

Retrospektif bir çalışmada Ferguson ve ark. 1980-2000 yılları arasında malignensi nedeniyle özofajektomi uygulanan 292 hastayı değerlendirmiş. Hastaların 78'inde (\%27) pulmoner komplikasyon görülürken, bu olgularda operatif mortalitede 4,5 kat artış gözlenmiş (5). Çalışmamızda beş hastada postoperatif dönemde pulmoner komplikasyon olarak pnömoni, atelektazi, pnömotoraks ve cilt altı amfizem gelişmiş olup bu da hastaların hastanede kalış sürelerinin artmasına neden olmuştur. Bir hasta anastomoz kaçağına bağlı pnömoni ve sepsis nedeniyle exitus olmuştur.

Postopertaif pulmoner komplikasyonları azaltmanın hayati parçası ameliyat öncesi ve sonrası sıkı solunum fizyoterapisidir. Pulmoner fizyoterapinin postoperatif pulmoner komplikasyonları önlemede etkili olduğunu gösteren iki çalışmada; Celli ve ark. üst abdominal cerrahi geçiren 81 hastayı değerlendirmişler, kontrol grubunda postoperatif komplikasyonlar \%88 iken, solunum ve öksürme egzersizi alanlarda \%32 bulunmuştur (6). Roukema ve ark. ise 153 üst abdominal cerrahi hastasında pulmoner komplikasyon insidansını kontrol grubunda $\% 60$, solunum ve öksürme egzersizi alan grupta ise \%19 olarak saptamışlardır (7). Biz de postoperatif dönemde pulmoner komplikasyonları azaltmak amacıyla hastalara solunum fizyoterapisi ve öksürme egzersizleri uyguladık.
Fagevik ve ark. tarafından yapılan çalışmada üst abdominal cerrahi geçiren 368 hasta değerlendirmeye alınmıştır. Tedavi grubuna preoperatif bilgilendirme, büzülmüş dudak solunumu ile birlikte solunum egzersizleri, burun çekme, öksürme teknikleri öğretilmiş ve yatakta pozisyon değiştirme ve erken mobilizasyonun önemi konusunda bilgilendirilmişlerdir. Kontrol grubundaki hastalara ise hiçbir uygulama yapılmamıştır. Postoperatif komplikasyon oranı tedavi grubunda $\% 6$, kontrol grubunda \%27 olarak bulunmuştur (8).

Sigara içimi postoperatif komplikasyon gelişimi için bir risk faktörü olarak belirlenmiştir ve komplikasyon riskinin azalması için sigaranın operasyondan en az 8 hafta önce bırakılması gerekmektedir $(9,10)$. Özofajektomiden 8 hafta öncesinden itibaren sigaranın tamamen bırakılması postoperatif pulmoner komplikasyonları azaltmada önemlidir. Sigara kullanım öyküsü olan 2 olgumuz operasyondan 8 hafta öncesi sigarayı bırakmıştı.

Yetersiz beslenme, postoperatif pulmoner komplikasyon gelişimini arttırmaktadır. Major cerrahi sonrası rutin total parenteral nutrisyon (TPN) uygulanması ile uygulanmamasını karşılaştıran bir meta-analizde, yetersiz enteral beslenme nedeniyle gelişen uzamış (10-14 günden daha uzun süre) ciddi malnutrisyon varlığı dışında TPN'nin faydalı olmadığı saptanmıştır (11). Yüksek riskli cerrahi hastalarında total enteral nutrisyon (TEN) ile TPN etkinliğini değerlendiren randomize prospektif araştırmaların dahil edildiği bir diğer meta-analizde ise TEN alan hastalarda TPN almakta olan hastalara göre septik komplikasyon gelişme riskinin daha düşük olduğu saptanmıştır (12). Biz de postoperatif dönemde anastomoz kaçağı ve sepsis gelişen bir olgumuz dışındaki diğer olgularımıza erken enteral nütrisyon başladık.

Postoperatif dönmelerde hastanın kilosu, komorbidite, cerrahinin türü gibi faktörlere bağlı olarak farklı sıvı gereksinimleri de olabilir. Postoperatif dönemde pulmoner komplikasyonları azaltmak için hastalara uygun sıvı tedavisi verilmelidir. Major cerrahiden sonra postoperatif sıvı tedavisinin amaçları; hücreye $\mathrm{O} 2$ sunumu sağlamak ve hipoperfüzyonun zararlı etkilerini önlemek için yeterli dolaşım hacmi sağlamak, aşırı sıvı yükleme ve ödemden sakınmaktır. Kalp hızı, kan basıncı, santral venöz basınç, periferik oksijen doygunluğu ve idrar çıkışı gibi fizyolojik parametrelerin rutin izlemi intravasküler volüm durumu değerlendirme ve sıvı tedavisini yönlendirmede sıklıkla kullanılır (13). Biz de postoperatif dönemde hastalarımıza kalp hızı, kan basıncı, santral venöz basınç, periferik 
oksijen doygunluğu ve idrar çıkışı gibi fizyolojik parametrelerin rutin izlemini yaparak uygun sıvı replasmanı yaptık.

Postoperatif ağrı, derin nefes almayı ve yeterli şiddette öksürmeyi engelleyerek, tidal volümü azaltarak pulmoner fonksiyonlarda ciddi bozulmaya neden olur (14). Uygun postoperatif analjezi ve özellikle epidural anestezi ameliyat sonrası pulmoner problemlerin azaltılmasında önemlidir. Biz de postoperatif dönemde hastalarımıza torakal epidural kateter kullanarak bupivakain ve fentanil ile etkili analjezi sağladık.

\section{Kaynaklar}

1. Wu J, Chai Y, Zhou XM, et al. Ivor Lewis subtotal esophagectomy with two-field lymphadenectomy for squamous cell carcinoma of the lower thoracic esophagus. World J Gastroenterol 2008;14:50849. [CrossRef]

2. Allen MS. Transthoracic resection of the esophagus. In Shields TW, LoCicero J, Reed CE, ed. General ThoracicSurgery, vol 2, 7th ed. Philadelphia: Lippincott Williams and Wilkins; 2009:1752-9.

3. Nafteux P, Coosemans W, De Leyn P, et al. Ivor Lewis esophagectomy. In: Sugarbaker D, Bueno R, Krasna MJ, ed. Adult Chest Surgery, 1st ed. New York City: McGraw- Hill; 2009:155-62.

4. Günlüoğlu MZ. Postoperatif Pulmoner Komplikasyonlar. Yücel O, Genç O, editörler. Journal of Clinical and Analytical Medicine Kitap Serisi, Akciğer Hastalıkları ve Tedavisi 2013; [CrossRef]

5. Ferguson MK, Durkin AE. Preoperative prediction of the risk of pulmonary complications after esophagectomy for cancer. J Thorac Cardiovasc Surg 2002;123:661-9.

6. Celli BR, Rodriguez KS, Snider GL. A controlled trial of intermittent positive pressure breathing, incentive spirometry, and deep breathing exercises in preventing pulmonary complications after abdominal surgery. Ann Rev Respir Dis 1984;130:12-5. [CrossRef]

7. Roukema JA, Carol EJ, Prins JG. The prevention of pulmonary complications after upper abdominal surgery in patients with noncompromised pulmonary status. Arch Surg 1988;123:30-4.

8. Fagevik Olsen M, Hahn I, Nordgren S, Lönroth H, Lundholm K. Randomized controlled trial of prophylactic chest physiotherapy in major abdominal surgery. Br J Surg 1997;84:1535-8.
Pnömoni gelişen ve mekanik ventilasyon ihtiyacı olan durumlarda entübasyondan 10 gün sonra trakeostomi tercih edilebilir $(5,15,16)$. Biz de postoperatif dönemde 2 olgumuza uzamış entübasyona sekonder trakeostomi açtık.

Özofagus cerrahisi sonrası pulmoner komplikasyon görülme oranı yüksek olup hastanede kalış süresini uzatmakta ve mortaliteyi arttırmaktadır. Dikkatli bir preoperatif değerlendirme, etkili solunum fizyoterapisi, erken enteral nütrisyon, postoperatif etkili analjezi ve postoperatif uygun sıvı replasmanı ile pulmoner komplikasyon oranları azaltılabilir.

9. Warner MA, Offord KP, Warner ME, Lennon RL, Conover MA, JanssonSchumacher $U$. Role of preoperative cessation of smoking and other risk factors in postoperative pulmonary complications: A blinded prospective study of coronary artery bypass. Mayo Clin Proc 1989;64:609-16.

10. Buist AS, Sexton GJ, Nagy JM, Ross BB. The effect of smoking cessation and modification of lung function. Am Rev Respir Dis 1976;114:115-22. [CrossRef]

11. Detsky AS, Baker JP, O'Rouke K, Goel V. Perioperative parenteral nutrition: a meta-analysis. Ann Intern Med 1987;107:195-203.

12. Moore FA, Feliciano DV, Andrassy RJ, et al. Early enteral feeding, compared with parenteral, reduces postoperative septic complications. The results of a meta-analysis. Ann Surg 1992;216:172-83.

13. Edwards MR, Grocott MPW. Perioperative Fluid and Electrolyte Therapy. Miller 8th edition, Chapter 59, Sayfa 1767-1808. 2015

14. Lewis KS, Whipple JK, Michael KA, Quebbeman EJ. Effect of analgesic treatment on the physiological consequences of acute pain. Am J Hosp Pharm 1994;51:1539-54.

15. Avendano CE, Patrick AF, Silvestri GA. Pulmonary complications after esophagectomy. Ann Thorac Surg 2002;73:922-6.

16. Shiozaki A, Fujiwara $\mathrm{H}, \mathrm{Okamura} \mathrm{H}$, et al. Risk factors for postoperative respiratory complications following esophageal cancer resection. Oncol Lett 2012;3:907-12. [CrossRef] 